\title{
Keeping rural children's hope to stay in the Senior High School through conditional cash transfer: An Indonesian case
}

\author{
Hendrawan Susilo | Setyo Tri Wahyudi* \\ Faculty of Economics and Business, Universitas Brawijaya
}

\begin{abstract}
Although the government has allocated cash transfer programs to reduce poverty and improve the education sector, the participation of senior high schools in rural areas in Indonesia is still meager. This research investigates the relationship between conditional cash transfers in Indonesia (Program Indonesia Pintar-PIP and Program Keluarga Harapan-PKH) with high school participation in children in Rural Indonesia. Using the 2018 socioeconomic survey data released by BPS, we found that children benefited from PIP children had a greater opportunity to participate in high school compared to those who did not. On the other hand, children from PKH beneficiary have a lower chance of attending high school, compared to those who come from families who do not receive PKH. Although conditional cash transfers generally have a positive effect on children's school participation, the success of conditional cash transfers relies on the knowledge of the people about the importance of children's education investments, simple program schemes, secure payment schemes, and efficient and effective technology-based controls.
\end{abstract}

Keywords: Conditional cash transfer, PKH, PIP, children education, Indonesia

\section{Introduction}

In 2020-2030, Indonesia is predicted to get a demographic bonus. This situation will have a positive impact if the quality of human development is excellent, but it will cause an increase in problems such as unemployment and poverty if mishandled. It is also considering that the labor force in Indonesia is still dominated by primary and junior high school graduates. The law has mandated that $20 \%$ of the government budget or around Rp 492 trillion in 2019 will be allocated to the education sector. The government tries to make primary and secondary education universal with a 12-year compulsory education program. These efforts include the development of educational infrastructure and its supporters, including the School Operational Assistance fund (Bantuan Operasional SekolahBOS) and improvement in the quality and quantity of teachers. However, the level of school participation at the secondary level is still low, especially in rural areas.

Based on data obtained from the Indonesian Statistical Bureau (Badan Pusat Statistik-BPS), school participation rates for children aged 16-18 years, mainly in rural areas, are still relatively low,

\footnotetext{
* Corresponding author at Jl. Veteran, Ketawanggede, Kec. Lowokwaru, Kota Malang, Jawa Timur 65145. Emails: wsetyotri@gmail.com and setyo.tw@ub.ac.id.
} 
around $66.09 \%$ in 2017. If we look at the secondary high school pure enrollment rates in Indonesia rural areas, it appears that the pure participation rate is still shallow at $47.73 \%$. It has been quite slow in its growth over the past five years, as shown in graph 1. The low participation rate of secondary schools, especially in rural areas, is currently become the concern of stakeholders and policy. The success in increasing this human resource will not only increase national competitiveness but will also help break the poverty chain.

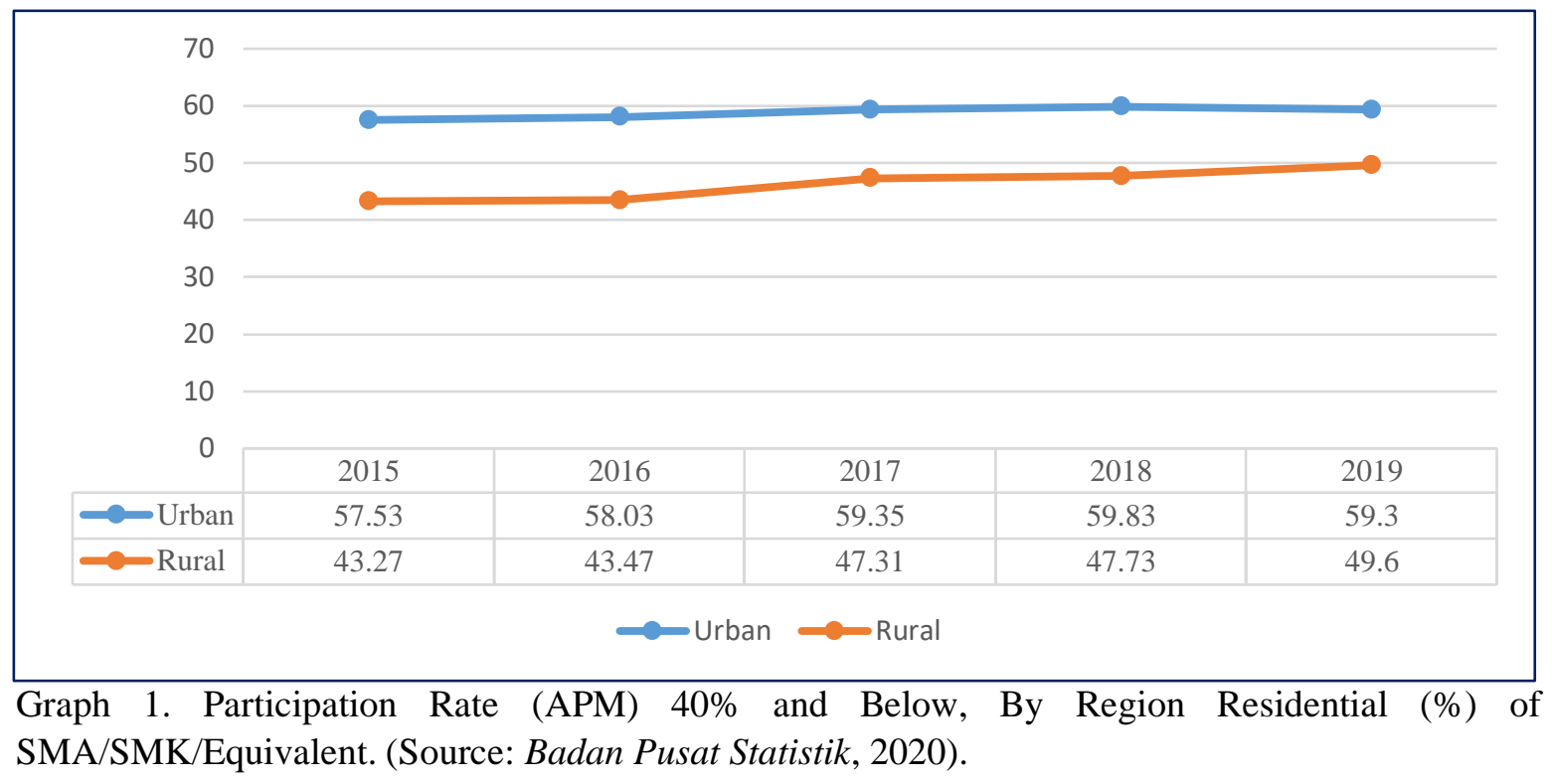

The provision of universal primary and secondary education services can be achieved through significant investments on the supply side. Nevertheless, there need interventions in the demand side to achieve universal school participation from households for educational needs (Bruns et al., 2003). The case for the poor, demand from households will not arise without efforts to reduce the cost barriers of education (direct and indirect). Even though children can complete primary school, secondary education usually has a higher burden on poor communities because of the additional costs and usually educational facilities far from where they live (Baird et al., 2013).

Related to this, the government has launched various programs, including PIP (Program Indonesia Pintar) and PKH (Program Keluarga Harapan-PKH). PIP and PKH are government programs with a cash transfer scheme. Cash Transfer is used throughout the world with two main objectives. First, to provide poor households with a minimum income threshold (reducing poverty) in the concise term. Second, to increase the accumulation of human capital for the next generation (reducing poverty in the long run) (Baird et al., 2010). Funds provided by the government through PKH in 2018 amounted to Rp 17.5 trillion with coverage of 10,000,232 beneficiary families. This value continues to increase from year to year since it was first launched in 2007 that accounts foronly Rp 39 billion.

The government also provides other conditional cash transfers in the PIP to help school-age children from vulnerable families to get education services until graduating from secondary education. While the coverage for PIP reaches 18,699,376 children in 2018, the distribution for high school level was 1,516,701 children and vocational high school 2,052,16 children, as shown in Graph 2 . 


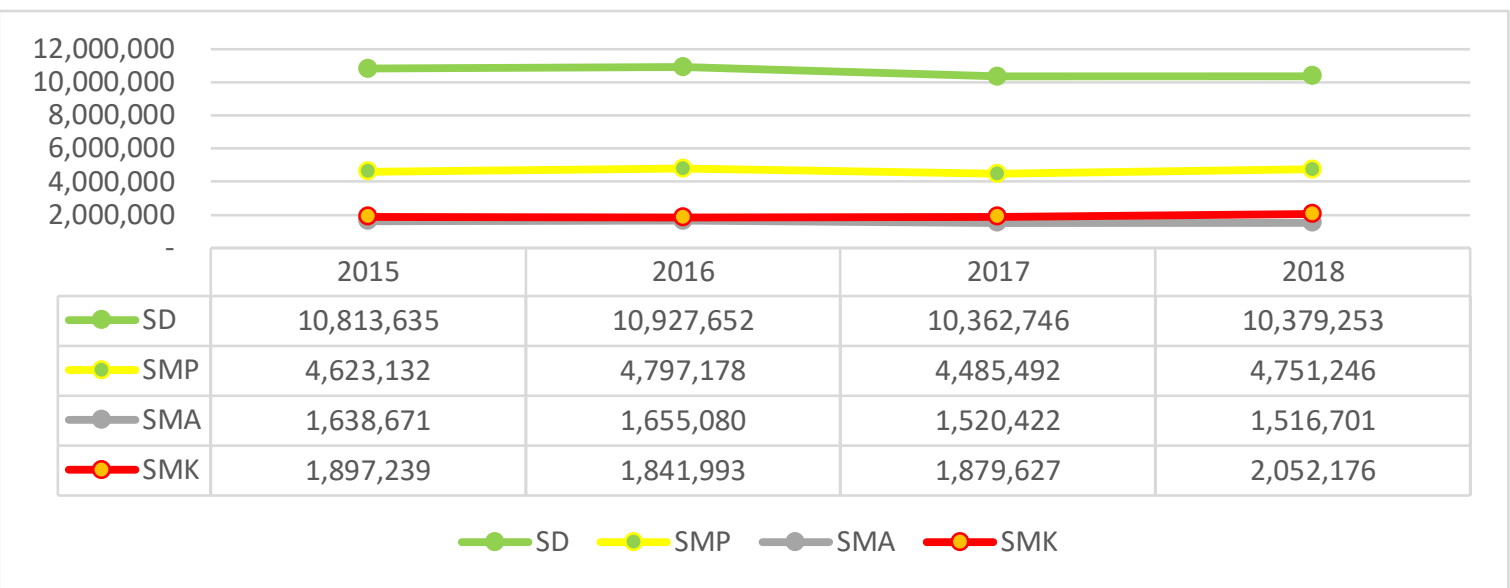

Graph 2. KIP Coverage (Source: Badan Pusat Statistik, 2020).

This study investigates the effect of PIP and PKH in rural areas on the propensity of children to participate in secondary schools in Indonesia. Secondary school participation in rural areas is still low compared to urban areas due to infrastructure inequality and other problems improvements in secondary education are more important for poverty reduction, health behaviors, gender equality, technology adoption (Duflo et al., 2017). Although there are many studies on the impact of cash transfers on children's education, no one has individually examined the impact of cash transfers on rural areas in Indonesia, and many studies have focused on primary education. In contrast, this research will focus on rural areas and at the senior secondary level.

\section{Literature Review}

The Second Theorem of Welfare Economic states that any desired allocation of utilities among community members can be achieved through competitive market operations by providing an adequately defined initial endowment (Nicholson and Snyder, 2009). Although in a perfect competition market with resources allocated efficiently among economic agents, the results are not necessarily ideal. The economic situation of people depends on the initial state of ownership of assets and good or bad fortune, in addition to their efforts in carrying out economic activities. Moreover, the government plays a vital role in carrying out income redistribution (Ihori, 2017). The government must allocate social policies to boost efficiency (competitive prices), thereby making the portion for agents as large as possible, and any inequality produced can be overcome with taxes and transfers at once (Nicholson and Snyder, 2009).

The government carries out redistribution functions, including progressive income tax, inheritance tax, social welfare program, and public pension and health insurance (Ihori, 2017). One part of the social welfare program is cash transfer. Cash transfers to the poor are an essential component of social protection policies and are a popular tool in development (Bastagli et al., 2016; Fiszbein and Schady, 2009). Cash transfer is not only as a safety net to protect the poor and redistribute resources among citizens, but also as an instrument that can facilitate the poor out of poverty (Daidone et al., 2015; Sabates et al., 2019). Two primary objectives of cash transfer is: (1) to provide poor households with a minimum income threshold (reducing poverty in the short term), and (2) to increase the accumulation of human capital for the next generation (reducing poverty in the long run) (Baird et al., 2010). 
In some countries, cash transfer has become the most extensive social assistance program, which includes millions of households, as is the case in Brazil and Mexico. Cash transfer is seen as a way to reduce inequality, especially in low and middle-income countries. Cash transfer has helped households escape the vicious cycle of poverty and promote child health, nutrition, and schooling (Fiszbein and Schady, 2009). Cash transfers over the past two decades have developed and are very popular as the most rational poverty alleviation strategy. Cash transfers are based on the idea that people need money to meet their needs, and they know best about their own needs (Hanlon et al., 2011).

\subsection{Human Capital Investment}

Investment in human resources, especially in children's education, is one of the central policies in low-income countries. Children from poor households can escape the poverty they can inherit from their parents by overcoming the problem of education (Hidayatina and Garces-Ozanne, 2019). Education policy in developing countries is focused on traditional supply-side interventions such as the construction of educational facilities, teachers, teaching materials. And not much has focused on demand-side interventions that focus on reducing costs and barriers to access and ignition of children's education (Kilburn et al., 2017).

The Cash transfer policy is expected to improve the educational outcomes of children in poor households through two channels. First, cash transfer will reduce the problems faced by low-income families with additional income (Akresh et al., 2013). Increased income can influence parents in reducing their pressure to force children to do work so that children can stay in school. Second, cash transfer will reduce the costs required for schools and allow parents to allocate money for school fees and supporters such as books and uniforms. These factors improve educational outcomes (Baez and Camacho, 2011). Although cash transfers do not address problems related to the quality of education, cash transfer can stimulate an increase in the demand side of education by helping to alleviate directly related education costs and opportunity costs that are lost when accessing education (Sabates et al., 2019).

Policymakers and stakeholders in most developing countries design and implement antipoverty programs to improve positive outcomes for children and young people (de Walque et al., 2017). One of the main approaches is the use of cash transfers to increase child development (Handa et al., 2016; Miller and Tsoka, 2012; Skoufias and Parker, 2001). Cash transfers are an extraordinary instrument for dealing with the vulnerability of poor households and promoting investment in human capital (Rosati, 2016; de Walque et al., 2017). By eliminating the economic difficulties of poor households, cash transfers can reduce poverty in the short term, while at the same time encouraging households to invest in the health, nutrition, and education of their children (Molina Millán et al., 2020; Rosati, 2016).

Even though primary education is universal and free, families are still faced with substantial tuition fees for school materials, food, travel, and uniforms (Langsten, 2017). These costs are a barrier for the poor to access education (Oketch et al., 2010). Conditional cash transfers can overcome these cost constraints. The conditional cash transfer program provides cash given to poor households by meeting specific requirements (Handa et al., 2016; de Walque et al., 2017).

Conditional cash transfer is a program that transfers cash, generally to poor households, provided that the household makes a predetermined investment such as investment in the human capital of their children. Most conditional cash transfer programs transfer money to homemakers or students with certain conditions (Fiszbein and Schady, 2009). The assumption behind this policy is that increased school participation and attendance will cause a decrease in children's participation in 
work activities inside and outside the household, and children can focus more on school-related activities (de Hoop and Rosati, 2014). Studies in 50 countries, mostly from the Latin American context, show that conditional cash transfers are strongly associated with increased school participation. Receiving cash transfers influences households fromsending their children to school (Snilstveit et al., 2016).

\subsection{PKH and PIP in Indonesia}

As one of the poverty reduction strategies in Indonesia, the government established a conditional cash transfer program namely the Program Keluarga Harapan (PKH). PKH was launched in 2007 aimed at improving health, education, and social welfare services for poor households. The main goalsare to improve the quality of human resources, especially for children from poor households. The long term goalsare to break the intergenerational poverty chain. PKH provides conditional cash transfers to beneficiaries for access to health and education services. PKH is a demand-side intervention by giving some money to increase opportunities in accessing health services and household opportunities in sending their children to educational facilities. This program is funded through the central government for school-age children (6-18 years old) in poor households to access education. At the same time, the money provided is intended to be used for education costs for schooling (Hidayatina and Garces-Ozanne, 2019).

The target of conditional cash transfers in education (PKH) is for poor students who have criteria that are a combination of family financial conditions, geographic targets, and selection of eligible individuals in a province. This cash assistance is provided quarterly to impoverished households with children or women who are breastfeeding pregnant by fulfilling several obligations related to health and education (The World Bank, 2012).

The Program Indonesia Pintar (PIP) is one of the conditional cash transfers designed to help school-age children from vulnerable low-income families to get education services until they graduate from secondary education, either through formal education channels. PIP is given in order to off set the personal costs of education of students, both direct and indirect costs (Ministry of Education, 2016). PIP is social security for children from low-income families to be able to access educational facilities. The purpose of PIP is to increase the participation of school-age children in accessing primary and secondary education. It increases the sustainability of education outcomes, reduce the gap in education participation between poor and prosperous communities, between gender and between rural and urban areas. It also increases students' readiness to enter the labor market. PIP is used to meet the costs of supporting education such as the purchase of school books and stationery, uniforms and school equipment, transportation costs to educational facilities, pocket money, and additional tuition fees and other needs related to educational support needs (Retnaningsih, 2017).

\subsection{Theoretical Framework}

The theoretical framework used as the basis is the "unitary model" of a family, where the head of the family is the decision-maker. This model assumes that households maximize their utility, are limited by time and budget. This model was previously used by several prior works (Becker, 1965; Becker and Lewis, 1973; Chiappori and Lewbel, 2015; Taylor and Adelman, 2003). Households get their utility from consuming goods/services and leisure. Income from households can be done by carrying out productive activities or external sources. Households must allocate their limited resources for production, consumption activities, and leisure time in achieving the highest utility level (Khanam et al., 2011). 
This framework is used in identifying how income shocks affect children's schools and the role of cash transfers in mitigating income shock (Hidayatina and Garces-Ozanne, 2019; De Silva and Sumarto, 2015). An exploration process is explored by connecting with child characteristics, characteristics of the head of the family, and the characteristics of the household and external interventions such as conditional cash transfer. This model follows (Bhuiya et al., 2019; Hidayatina and Garces-Ozanne, 2019; De Silva and Sumarto, 2015), the problem of maximizing utility in households is mentioned as follows.

$\max _{C, L, S} U(C, L, S: X)$

$\mathrm{U}$ is a concave function of utility based on household consumption (C), child leisure (L), and child's schooling (S) as well as exogenous characteristic vectors in individuals, heads of households, and families (X). Education is one example of services consumed by households. Households get higher utility from the excellent school performance of their children. To achieve this result, they must allocate some household resources for education for their children (Bhuiya et al., 2019). Time constraints limit the maximizing family utility:

$T=L \perp S \perp E$

Where T is total time, $\mathrm{L}$ is leisure time, $\mathrm{S}$ is the child's school attendance, and $\mathrm{E}$ is a child's work time. The head of the household regulates the allocation of the total time of the child, both for leisure activities, attending school, or working both for commercial purposes or domestic work. Household budget constraints in maximizing utility by including household income $\mathrm{Y}$ and government fiscal policy in the context of the distribution of income G. Assuming that the income of parents $\mathrm{Y}$ is exogenous (adult labor supply and leisure tobe exogenous), so when parents do not work not by choice but because of external conditions of the market (De Silva and Sumarto, 2015). Income from household production with consumption and production costs are as follows.

$P_{c} C+P_{S} S \leq Y+W E+G$

Where $\mathrm{P}_{\mathrm{c}}$ is the price of consumption, $\mathrm{P}_{\mathrm{s}}$ is the price of school (school fees), and $\mathrm{W}$ is the income of the child labor, $\mathrm{E}$ is the time of work of the child, $\mathrm{Y}$ is the income of parents, $\mathrm{G}$ is the income from government fiscal policy.

The household must do a combination of prices for consumption and schooling regarding the household income, the wage rate for children and cash transfers that are given to children participating in school to maximize the utility. In the context of cash transfers, cash transfers reduce school fees (Hidayatina and Garces-Ozanne, 2019). An increase in G (cash transfer program) will reduce school costs such as books, transportation, uniforms, shoes, and will increase children's participation in schooling (Edmonds and Schady, 2012). Cash Transfer Programs can affect the behavior of recipient households, especially families who experience financial vulnerability, are more likely to be affected by income constraints (de Hoop and Rosati, 2014).

\subsection{Previous Study}

In a study in Mexico by Skoufias and Parker (2001), PROGRESA (cash transfer in Mexico) had an extraordinarily positive impact on attendance rates for male and female middle school students aged between 12-17. The marginal effects for boys between 12 and 17 are all significant in each round after the program's launch. For students, the effect of this program is indeed higher. Armecin et al. (2006) researching a five-year Early Childhood Deve lopment project in the Philippines in 1999, 
found that PAUD has a positive contribution to participate in children's cognitive, language and social-emotional skills along with other beneficial effects

Son and Florentino (2008) found that cash transfers per child per month could reduce the proportion of children not attending school in all households from $5.81 \%$ to $1.56 \%$. A $6.7 \%$ increase in school attendance among the poor indicates that conditional cash $s=$ transfer will be more effective in increasing school attendance for children in poor households than in all households. Amarante et al. (2011), researching cash transfers in Uruguay, found that youth attendance rates will increase between 6 and 8 percentage points if receiving cash transfers. Ferrando (2013) also found that conditional cash transfer in Uruguay (Plan de Atencíon Nacional a la Emergencia Social PANES) also helped increase school attendance for children included in beneficiary families.

Nevertheless, the effect is only significant for women and children in the first grade. Among girls, conditional cash transfer reduced absence from 0.6 to 0.9 days a month. This program does not have a significant effect on other school outcomes, such as promotion or repetition. De Brauw and Hoddinott (2011) conducted a study in Mexico, comparing the impact of Cash Transfer on child school enrolment between beneficiary households and those who did not. It finds that the impact is higher for beneficiaries, especially for children in the transition to secondary school.

Giang and Nguyen (2017) study in Vietnam found that cash transfers have a positive effect on school enrolment and poverty alleviation. Research in Honduras with indigenous and nonindigenous research objects by Molina Millán et al. (2020), found that cash transfers on nonindigenous populations have a positive and robust impact on educational outcomes in all age groups. These included an increase of more than 50\% in secondary school completion rates and achieving university studies: increased value acquisition and enrolment in school-age children in children who are beneficiaries. However, on the indigenous population, the impact is minimal. Taking Mexico as the object of research De Brauw and Hoddinott (2011) compares the impact of subsidies on the participation of school children between receiving and not receiving households. Furthermore, the results show that a higher impact occurs on conditioned/assisted households, especially among children in the transition to high school.

In the case of the Malawian study, the (Difference-in-Difference) DID analysis shows that households with children who received UCT experienced a 5\% difference in school enrollment, higher education investment, and lower absenteeism in schools compared to comparable households without cash transfers (Miller and Tsoka, 2012). The findingsrevealed that girls in intervention households decreased the number of absenteeism than boys. Also, both gender in intervention households and comparative households diminished their absence (Miller and Tsoka, 2012).

Nanda et al. (2014) in India used a quasi-experimental impact evaluation design on the ApniBeti Apna Dhan (ABAD) program on educational outcomes. They found that a higher number of girls who became beneficiaries of social interventions remained in school compared to female children who did not receive benefits from social interventions. Handa et al. (2016) show that households that receive cash transfers invest in the education of their children compared to households that do not receive any social grants. However, cash transfers do not impact households that do not invest in the education of their children before receiving a grant. In Honduras, the provision of conditional cash transfer in households with children shows a positive and significant impact of conditional cash transfer on boys and girls of various ages on the achievement of classrooms and school competitions. While the impact is overwhelming in older children, the long-term impact on boys and girls is minimal (Millán et al., 2018). 


\section{Data and Methodology}

In order to meet the research objectives, we used the 2018 Indonesian Socio-Economic Survey (Susenas) data. The 2018 Susenas included 295,155 families and 1,131,825 individuals. Susenas is a recurring cross-section survey and represents national conditions. It consists of two modules, namely the core and module. The core component contains basic socio-demographic information about households and individuals and is carried out annually. The module component contains detailed information about the household. There are three different modules, namely consumption, health, and education, which are carried out alternately every year. The sample in this study were school-aged children between 16 and 18 years who represented the age of high school children. Also, this research is focused on rural areas only. From the limitation of the sample, there were 34,040 children aged 16 to 18 years living in the rural area.

Susenas is implemented at the household level but also includes several individual characteristics such as age, gender, employment status, and education. At the household level includes information on household expenditure, main household economic activities, ownership of goods, participation in poverty alleviation programs, housing conditions, and cash transfer assistance to the family.

The binomial logit model will be used to analyze the PKH and KIP distinction on a child's tendency to attend high school. The model is developed from the combination model, which is used by Bui et al. (2020); Janssens et al. (2019); and Suryadarma et al. (2006) with little modification. To estimate we employed three different models, we will first estimate adding control variablesto the individual characteristics of the child, then using the characteristics of the head of the family and family characteristics. Finally, we will use all of the control variables.

$$
\begin{aligned}
& L i=\ln \left(\frac{P i}{1-P i}\right) \\
& E_{c p h}=\beta 0+\beta_{1}(P I P)+\beta(P K H)+\beta X_{c}+\mu \\
& E_{c p h}=\beta 0+\beta_{1}(P I P)+\beta(P K H)+\beta Y_{p}+\beta X_{h}+\mu \\
& E_{c p h}=\beta_{0}+\beta_{1}(P I P)+\beta(P K H)+\beta X_{c}+\beta Y_{p}+\beta X_{h}+\mu
\end{aligned}
$$

The dependent variable is a dummy for school participation for children $c$ who have parents living in the household $h$. The main independent variables are the dummy variable for PIP recipient children and dummy for children living in families receiving PKH. One way to minimize the potential for unobservable variables is to add as many control variables as possible, following what was done (Cameron, 2009; Jalan and Ravallion, 2003). The control variables used include variables related to the characteristics of the child, characteristics of the head of the household, and household characteristics. The determination of these control variables follows the control variables that have been widely used in the literature such as (Bui et al., 2020; Deolalikar, 1993; Dostie and Jayaraman, 2006; Janssens et al., 2019; Lincove, 2009; Orazem and King, 2007; Rosati, 2003; Sabates et al., 2019).

The variables related to individual characteristics (C) contain the age of the child, a dummy for a child's work status, a dummy for female students, and a child's marital status. Furthermore, the variables related to the characteristics of the family head $(\mathrm{P})$ consist age of the household head, the level of education which was stated by the length of the school, the number of hours worked by the head of the household, and the dummy for the head of the male household. Furthermore, variables 
with household characteristics consisting of non-food expenditure as a measure of household welfare, dependency ratio measures the level of dependency in households by dividing the number of family members of non-productive age compared to the number of families at productive age and variable indicators of household wealth indicators such as ownership of land, house, floor size, and electric power in the house.

\section{Result and Discussion}

\subsection{Descriptive Statistic}

Out of 34,040 school-aged children between 16 and 18 who live in the sample villages, there are 6,861 beneficiaries of the smart Indonesia card (KIP). In contrast, there were 7,504 children in the families of PKH recipients. In general, KIP beneficiaries, PKH Beneficiaries, and all sample almost the same characteristics, but several variables have different features among different beneficiaries. In general, the percentage of marriage rates among school-age children is 5\%. Compared to the KIP beneficiaries and PKH beneficiaries, the portion of the marital status of PKH recipients is higher at $3.43 \%$ compared to KIP recipients is only $0.8 \%$. On average, the education level of parents of KIP beneficiaries (4.60) was higher than PKH beneficiaries (4.04) but was still below the average of all observations (4.722). Non-food expenditure by PKH beneficiary households is lower than KIP recipient families and is still below the overall observation rate. However, on the other hand, the average dependency ratio and household size for PKH recipient families are higher than KIP beneficiary families. This might indicate that the economic conditions of PKH beneficiary families are more vulnerable compared to KIP recipient families. Table 1 shows descriptive statistics of all variables used in this study.

\subsection{Estimation Result}

Table 2 discusses the results of logit estimation on three different models. First, in model 1 , with the child control variable, it is seen that the main explanatory variable PKH or PIP is entirely significant for children's participation in high school. While in model 2 and model 3, PIP is significant, but $\mathrm{PKH}$ is not.

The estimation results in model 1 show that children in PKH recipient families oppose having more money for the family, which is 0.844 times compared to children in non-recipient households. While in model 2 and model 3, but the results are not significant, but show a negative direction. PKH recipient children likely attend school lower than non-beneficiary families. The main explanatory variable PIP is significant in three models and has a positive direction towards aid providers in the form of PIP increasing children's chances of going to school.

In model 1, it seems that PIP recipient children have a 2.80 higher chance of attending school compared to non-recipient children. In model 2, the control variable in the form of household characteristics and household characteristics shows that children who receive PIP have a 4.38 times greater chance than those who do not. Then in model 3, by adding a variable set of characteristics of children, characteristics of the head of the household, and characteristics of the household, it shows that PIP recipient children have the opportunity to attend school 2.94 times compared to non-recipient children. The three models show that the control variable of the child characteristics increases the magnitude of the estimated coefficient that is far greater than the variable characteristics of the head of the household and the characteristics of the household. Model 1 has a determination coefficient of $13.72 \%$, while model 2 , which adds control variables of family characteristics and household 
characteristics, only has a coefficient of determination of $5.79 \%$. Model 3 that was approved by all sets of control variables, has a coefficient of determination of $15.04 \%$.

Table 1. Descriptive Statistics

\begin{tabular}{|c|c|c|c|c|c|c|}
\hline \multirow[t]{2}{*}{ Variable } & \multicolumn{2}{|c|}{$\begin{array}{c}\text { All observations } \\
\text { Obs. } 34,040 \\
\end{array}$} & \multicolumn{2}{|c|}{$\begin{array}{c}\text { KIP Beneficiaries } \\
\text { Obs. } 6,861\end{array}$} & \multicolumn{2}{|c|}{$\begin{array}{c}\text { PKH Beneficiaries } \\
\text { Obs. } 7,504 \\
\end{array}$} \\
\hline & Mean & Std. Dev. & Mean & Std. Dev. & Mean & Std. Dev. \\
\hline school & 0.8887 & 0.3145 & 0.9621 & 0.1910 & 0.8979 & 0.3028 \\
\hline kip & 0.2016 & 0.4012 & - & - & 0.4663 & 0.4989 \\
\hline$p k h$ & 0.2204 & 0.4146 & 0.5100 & 0.4999 & - & - \\
\hline female_c & 0.4672 & 0.4989 & 0.4819 & 0.4997 & 0.4560 & 0.4981 \\
\hline$a g e \_c$ & 16.9861 & 0.8045 & 16.8525 & 0.7844 & 16.9510 & 0.8023 \\
\hline married_c & 0.0535 & 0.2251 & 0.0083 & 0.0908 & 0.0344 & 0.1822 \\
\hline workstat_c & 0.2158 & 0.4114 & 0.1258 & 0.3316 & 0.2265 & 0.4186 \\
\hline umur_krt & 48.6034 & 10.0202 & 48.5955 & 9.2863 & 48.8380 & 9.1787 \\
\hline$k \_m a l e \_r t$ & 0.8830 & 0.3214 & 0.8860 & 0.3178 & 0.8830 & 0.3214 \\
\hline eduparent_rt & 5.5734 & 4.7238 & 4.6044 & 3.8461 & 4.0434 & 3.4421 \\
\hline workhour_rt & 40.7453 & 18.9692 & 41.1612 & 18.6484 & 40.9050 & 18.2570 \\
\hline nonfoodexp & $1,686,671$ & $1,863,638$ & $1,347,663$ & $1,027,446$ & $1,201,267$ & 850,555 \\
\hline depratio & 0.4089 & 0.3922 & 0.4648 & 0.4133 & 0.5244 & 0.4184 \\
\hline ownhouse & 0.9176 & 0.2750 & 0.9200 & 0.2713 & 0.9227 & 0.2671 \\
\hline hhsize & 5.1140 & 1.9167 & 5.3236 & 1.8519 & 5.7144 & 1.9440 \\
\hline land & 0.8234 & 0.3813 & 0.8166 & 0.3870 & 0.8221 & 0.3825 \\
\hline watt & 549.6798 & 410.7007 & 502.3247 & 376.6558 & 464.0125 & 364.4065 \\
\hline
\end{tabular}

Based on the result in table 2, we can see that all control variables of child characteristics in model 1 and model 2 show a significant relationship with a negative direction. Girls have a higher chance of going to school than boys and increasing the age of children to attend school. Marital status Lost the child's chance to go to school. While children who work reduce the chances of children to go to school.In the control variable of household heads in model 2 and model 3, only two significant, they are the age of the head of the household and the education of the head of the household. The higher the age of the head household, the chances of children enrollin school are higher. The level of education of parents also increases children's chances of going to school. In contrast, two other variables, namely male household head and the number of hours worked by parents, did not significantly influence.

In the household characteristics variable, there are three significant variables and three nonsignificant variables. Non-food expenditure installed electric power, and land ownership is significant. The insignificant variables are the dependency ratio, homeownership, and home floor area. Variable Increased non-food expenditure increases, leaning to attend school. Increasing the installed electric power increases children's chances of going to school, while land ownership increases children's chances of going to school. 
After controlling for individual characteristics, head of household characteristics, and family characteristics, we found that the relationship of children in families receiving PKH with children's school participation had a negative but not significant relationship. However, by controlling only individual characteristics, it is known that children in recipient families reduce the chances of children to attend school. One possible explanation for this finding is PKH program has not had a permanent impact on the preferences and beliefs of parents and children in the benefits of education. Also, although preferences change, there are structural factors that hold back the shift in preferences (Baez and Camacho, 2011). The PKH is given to every household with the help of a taker being a woman. Assistance is provided at the family level so that decisions on use are at the household level. PKH provides specific requirements, such as the presence of $85 \%$ of children every month at school. If there are no altruistic motives of parents to invest in children's education, then it causes the allocation of children's education to be used for other purposes.

Table 2. Estimation Result Summary

\begin{tabular}{|c|c|c|c|c|c|c|c|c|c|}
\hline \multirow[b]{2}{*}{ Variable } & \multicolumn{3}{|c|}{ Model 1} & \multicolumn{3}{|c|}{ Model 2} & \multicolumn{3}{|c|}{ Model 3} \\
\hline & $\begin{array}{l}\text { Odds } \\
\text { Ratio }\end{array}$ & S.E & Sig. & $\begin{array}{l}\text { Odds } \\
\text { Ratio }\end{array}$ & S.E & Sig. & $\begin{array}{l}\text { Odds } \\
\text { Ratio }\end{array}$ & S.E & Sig. \\
\hline \multicolumn{10}{|l|}{ Main Independent } \\
\hline PKH & 0.844 & 0.039 & 0.00 & 0.939 & 0.043 & 0.18 & 0.917 & 0.049 & 0.07 \\
\hline PIP & 2.805 & 0.195 & 0.00 & 4.38 & 0.298 & 0.00 & 2.9454 & 0.0697 & 0.00 \\
\hline \multicolumn{10}{|l|}{ Individual } \\
\hline Child (Female) & 0.886 & 0.035 & 0.00 & & & & 0.8837 & 0.0409 & 0.00 \\
\hline Child Ages & 0.77 & 0.018 & 0.00 & & & & 0.7678 & 0.024 & 0.00 \\
\hline Child Marital Status & 0.174 & 0.01 & 0.00 & & & & 0.1905 & 0.0594 & 0.00 \\
\hline Child Working Status & 0.248 & 0.009 & 0.00 & & & & 0.2779 & 0.0403 & 0.00 \\
\hline \multicolumn{10}{|l|}{ Household Head } \\
\hline Parent Ages & & & & 1.015 & 0.001 & 0.00 & 1.004 & 0.0018 & 0.03 \\
\hline Parent (Male) & & & & 0.989 & 0.054 & 0.84 & 0.9759 & 0.0579 & 0.67 \\
\hline Parent Education & & & & 1.091 & 0.005 & 0.00 & 1.0601 & 0.0049 & 0.00 \\
\hline Parent Work Hours & & & & 1.001 & 0.000 & 0.14 & 1.0004 & 0.001 & 0.64 \\
\hline \multicolumn{10}{|l|}{ Household } \\
\hline $\begin{array}{l}\text { Non Food } \\
\text { Expenditure }\end{array}$ & & & & 1 & $1.70 \mathrm{E}-08$ & 0.00 & 1 & $1.60 \mathrm{E}-08$ & 0.00 \\
\hline Dependency Ratio & & & & 1.072 & 0.055 & 0.17 & 1.0699 & 0.0544 & 0.21 \\
\hline Own House & & & & 0.919 & 0.063 & 0.22 & 0.8326 & 0.0738 & 0.01 \\
\hline Floor Size & & & & 1.013 & 0.01 & 0.20 & 1.0281 & 0.01117 & 0.01 \\
\hline Electricity Power & & & & 1.181 & 0.055 & 0.00 & 1.1852 & 0.0494 & 0.00 \\
\hline Own Land & & & & 1.0003 & 0.000 & 0.00 & 1.0001 & 4.93E-05 & 0.01 \\
\hline Constanta & 1223.3 & 500.651 & 0.00 & 1.2181 & 0.15 & 0.11 & 544.91 & 0.4298 & 0.00 \\
\hline LR chi2(6) & 3261.4 & & & 1376.92 & & & 3575.08 & & \\
\hline Prob $>$ chi 2 & 0 & & & 0 & & & 3575.08 & & \\
\hline Pseudo R2 & 0.1372 & & & 0.0579 & & & 0.1504 & & \\
\hline
\end{tabular}

Another explanation, as suggested by De Brauw and Hoddinott (2011), is the occurrence of administrative problems in the context of monitoring the use of the program. This problem is because compliance with these requirements is difficult and expensive to control. PKH is still experiencing problems in determining the target beneficiaries, program supervision, and program administration. Revealed Widianto (2013), the problem is: the verification process has not been carried out properly, 
and payments to beneficiary households are not timely. Also, rural communities demand to work for children aged 16-18 years in order to increase family income even higher, especially the first child will have a moral burden on the family to get income for family living expenses.

In all three models, the effect of PIP on school participation is significant and has a positive direction. This finding is in line with the excellent implementation of the PIP program. The government uses a scheme of assisting with smart Indonesia cards. The government distributes smart Indonesian cards to individuals who meet the requirements. The financing component for PIP is very targeted, which consists of transportation funds to access educational facilities, additional costs related to attendance at schools such as uniforms, stationery, and books. Assisting using a card scheme makes it easy for beneficiaries to use it efficiently because many businesses widely accept the card. This condition makes it easy for the recipient child to apply for assistance from the government. Control over the use of funds available on the card is excellent because it can only be used to buy specific items that have been set by the government.

The finding is in line with some previous research on conditional cash transfers. The positive impact of the conditional cash transfer program on children's participation in schools is based on the requirements that must be met. This forces households to behave following government intervention. This requirement will increase household demand for education services (De Brauw and Hoddinott, 2011; Norbert Schady and Maria Caridad Araujo, 2008; Skoufias and Parker, 2001). Furthermore, although monitoring the requirements on cash transfers is very difficult, when achieved, for example by simplifying the system, it can have a reverse effect, because the possibility of children dropping out of school in poor households is very high (Amarante et al., 2011).

In the control variable of individual characteristics, there are four variables that statistically significantly influence school participation, all of which have a negative direction on school participation. It means that all control variables of individual characteristics reduce the chance of children's school participation. In the age variable of the child, the older the level of school participation, the lower the chance for children to go to school. This finding contrasts with research Owusu-Addo et al. (2020), which states that when parents cannot send all of their children to school, they will decide on the oldest child tot be given priority. Conditions in rural areas are inversely proportional because the oldest child usually chooses to work to help the family economy rather than go to school. The findings of girls who are less likely to go to school are in line with research by Glick and Sahn (1999); and Maertens and Verhofstadt (2013). Marital status decreases children's chances of going to school. This finding is following the conditions in Indonesia, especially certain ethnic groups. Cultural factors have an important role in this young marriage, for example, the Madurese in Pontianak, who traditionally prepare for marriage after they finish elementary school (Suryadarma et al., 2006). Marital status decreases children's chances of going to school, this is related to the expectations of parents in the village, that children aged 16 to 18 years can contribute more to agricultural work than to school (Owusu-Addo et al., 2020).

On the characteristics of the head of household, education level of the head of the family and the age of the head of the Household are statistically significant and increase the chance of participation of the child's secondary school. At the variable level of education of the head of the Household, the higher the level of education of parents increases the chances of children's school participation. This finding is in line with the literature by Tansel (1997). The higher the education level of parents, the more aware of the importance of investment in education. Education will provide provisions for children to enter the labor market and, in the future, will provide high returns. The age variable indicates that getting older increases the chances of a child's secondary school participation. 
The explanation of this finding is, the older the age, the more savings the parents should have, and the family is ready to invest some of their money in children's education.

In the characteristics of the household, three variables are statistically significant; all three have a positive direction in increasing the chances of children going to school. The variables are nonfood expenditure, electric power, and land ownership. This is in line with previous studies Glick and Sahn (1999); Grimm (2011); and Tansel (1997), where wealth from households is an essential determinant in secondary school enrolment. The higher the electrical power installed correlates with, the more prosperous the family. Furthermore, land ownership is part of the social status of the owner's family. Non-food expenditure reflects the secondary and tertiary needs of the Household. The higher the secondary or tertiary expenditure of a household, describing its welfare.

\section{Conclusions and Policy Implications}

This research contributes to fulfill of the knowledge gap in the literature, that is the relationship between conditional cash transfer in (PIP and $\mathrm{PKH}$ ) and secondary education in rural areas in Indonesia. Using the 2018 Indonesian socio-economic survey data, we empirically analyzed the relationship between different conditional cash transfer schemes (PIP and PKH) and the proportion of child secondary school enrollment. We found that PIP-beneficiary children had a greater opportunity to participate in high school compared to those who did not. For children who are in $\mathrm{PKH}$, recipient families less likely to attend high school compared to those those who come from families who do not receive PKH. Although PIP and PKH are conditional cash transfers that have requirements related to education, the distribution and supervision schemes of the programs are different. It is perhaps because PIP has a more straightforward program mechanism and reliable control by utilizing card-based and digital payment technology. So the chance for misuse of its utilization is low. Whereas in the case of $\mathrm{PKH}$, the two models are insignificant, and one model has a negative direction because compliance with the requirements is difficult and expensive to control, and PKH does not have a permanent impact on the preferences and beliefs of parents and children.

Our results have important policy implications. Although conditional cash transfers generally have a positive effect on children's school participation, the success of conditional cash transfers must pay attention to public knowledge about the importance of children's education investments, simple program schemes, secure payment schemes, and efficient and effective technology-based control. The results of this study suggest the government to incorporate the existing education components in PKH into the PIP scheme because PIP is more effective and efficient in increasing children's school participation.

\section{References}

Akresh, R., Walque, D. De and Kazianga, H. (2013), “Cash transfers and child schooling: Evidence from a randomized evaluation of the role of conditionality", World Bank Policy Research, available at:https://doi.org/10.1037/e547172013-001.

Amarante, V., Ferrando, M. and Vigorito, A. (2011), "School Attendance, Child Labor, and Cash Transfers. An Impact Evaluation of PANES", Poverty and Economic Policy ..., No. 85, p. 11239.

Armecin, Graeme \& Behrman, Jere R. \& Duazo, Paulita \& Ghuman, Sharon \& Gultiano, Socorro \& King, Elizabeth M. \& Lee, N. (2006), "Early childhood development through an integrated program : evidence from the Philippines", Policy Research Working Paper Series 3922, World Bank.

Baez, J.E. and Camacho, A. (2011), "Assessing the long-term effects of conditional cash transfers on human capital: evidence from Colombia”, World, available at:https://doi.org/10.1596/1813-9450-5681.

Baird, S., Chirwa, E., McIntosh, C. and Özler, B. (2010), "The short-term impacts of a schooling conditional cash transfer program on the sexual behavior of young women", Health Economics, available 
at:https://doi.org/10.1002/hec.1569.

Baird, S., Ferreira, F.H.G., Özler, B. and Woolcock, M. (2013), "Relative Effectiveness of Conditional and Unconditional Cash Transfers for Schooling Outcomes in Developing Countries: A Systematic Review", Campbell Systematic Reviews, Vol. 9 No. 1, pp. 1-124.

Bastagli, F., Hagen-Zanker, J., Harman, L., Barca, V., Sturge, G., Schmidt, T. and Pellerano, L. (2016), "Cash transfers: what does the evidence say", A Rigorous Review of Programme Impact and the Role of Design and Implementation Features. London: ODI.

Becker, G.S. (1965), "A Theory of the Allocation of Time", The Economic Journal, available at:https://doi.org/10.2307/2228949.

Becker, G.S. and Lewis, H.G. (1973), "On the Interaction between the Quantity and Quality of Children", Journal of Political Economy, available at:https://doi.org/10.1086/260166.

Bhuiya, M.M.M., Khanam, R., Rahman, M.M. and Nghiem, S. (2019), "Microcredit participation and child schooling in rural Bangladesh: Evidence from a cross-sectional survey", Economic Analysis and Policy, Elsevier B.V., Vol. 64, pp. 293-301.

De Brauw, A. and Hoddinott, J. (2011), "Must conditional cash transfer programs be conditioned to be effective? The impact of conditioning transfers on school enrollment in Mexico", Journal of Development Economics, available at:https://doi.org/10.1016/j.jdeveco.2010.08.014.

Bruns, B., Mingat, A. and Rakotomalala, R. (2003), The World Bank, A Chance for Every Child: Achieving Universal Primary Education by 2015, World Bank, Washington, DC, available at:https://doi.org/10.4337/9781847202888.00013.

Bui, T.A., Nguyen, C.V., Nguyen, K.D., Nguyen, H.H. and Pham, P.T. (2020), "The effect of tuition fee reduction and education subsidy on school enrollment: Evidence from Vietnam", Children and Youth Services Review, available at:https://doi.org/10.1016/j.childyouth.2019.104536.

Cameron, L. (2009), "Can a public scholarship program successfully reduce school drop-outs in a time of economic crisis? Evidence from Indonesia", Economics of Education Review, available at:https://doi.org/10.1016/j.econedurev.2007.09.013.

Chiappori, P.A. and Lewbel, A. (2015), "Gary Becker's A theory of the allocation of time", Economic Journal, available at:https://doi.org/10.1111/ecoj.12157.

Daidone, S., Pellerano, L., Handa, S. and Davis, B. (2015), "Is graduation from social safety nets possible? Evidence from sub-saharan africa", IDS Bulletin, available at:https://doi.org/10.1111/1759-5436.12132.

Deolalikar, A.B. (1993), "Gender differences in the returns to schooling and in school enrollment rates in Indonesia", Journal of Human Resources, available at:https://doi.org/10.2307/146297.

Dostie, B. and Jayaraman, R. (2006), "Determinants of school enrollment in Indian villages", Economic Development and Cultural Change, available at:https://doi.org/10.1086/497006.

Duflo, E., Dupas, P. and Kremer, M. (2017), "The Impact of Free Secondary Education: Experimental Evidence from Ghana", Massachusetts Institute of Technology Working Paper Cambridge, MA.

Edmonds, E. V. and Schady, N. (2012), "Poverty alleviation and child labor", American Economic Journal: Economic Policy, available at:https://doi.org/10.1257/pol.4.4.100.

Education, M. of. (2016), "DIKBUD_MAJALAH_edisi4_OK.pdf".

Ferrando, M. (2013), "Cash Transfers and School Outcomes: the case of Uruguay".

Fiszbein, A. and Schady, N. (2009), Conditional Cash Transfers- Reducing Present and Future Poverty- A World Bank Policy Research Report, The World Bank, available at:https://doi.org/10.1001/jama.298.16.1900.

Giang, L.T. and Nguyen, C.V. (2017), "How would cash transfers improve child welfare in Viet Nam?", Children and Youth Services Review, Elsevier, Vol. 82 No. September, pp. 87-98.

Glick, P. and Sahn, D.E. (1999), "Schooling of girls and boys in a West African country: The effects of parental education, income, and household structure", Economics of Education Review, available at:https://doi.org/10.1016/S0272-7757(99)00029-1.

Grimm, M. (2011), "Does household income matter for children's schooling? Evidence for rural Sub-Saharan Africa", Economics of Education Review, Vol. 30 No. 4, pp. 740-754.

Handa, S., Natali, L., Seidenfeld, D., Tembo, G., Davis, B., Tembo, G. and Davis, B. (2016), "Can Unconditional Cash Transfers Lead to Sustainable Poverty Reduction? Evidence from two governmentled programmes in Zambia", Unicef, No. August, p. 58.

Hanlon, J., Barrientos, A. and Hulme, D. (2011), "Just Give Money to the Poor : The Development Revolution 
from the Global South Just Give Money to the Poor: The Development Revolution from the Global South", Development, available at:https://doi.org/10.1007/s13398-014-0173-7.2.

Hidayatina, A. and Garces-Ozanne, A. (2019), "Can cash transfers mitigate child labour? Evidence from Indonesia's cash transfer programme for poor students in Java", World Development Perspectives, Elsevier, Vol. 15 No. July, p. 100129.

de Hoop, J. and Rosati, F.C. (2014), "Cash Transfers and Child Labor", The World Bank Research Observer, available at:https://doi.org/10.1093/wbro/lku003.

Ihori, T. (2017), "Public Finance and a Review of Basic Concepts", available at:https://doi.org/10.1007/978981-10-2389-7_1.

Jalan, J. and Ravallion, M. (2003), "Does piped water reduce diarrhea for children in rural India?", Journal of Econometrics, available at:https://doi.org/10.1016/S0304-4076(02)00158-6.

Janssens, C., Van den Broeck, G., Maertens, M. and Lambrecht, I. (2019), "What if mothers are entrepreneurs? Non-farm businesses and child schooling in rural Ghana", Journal of Rural Studies, Elsevier, Vol. 66 No. January, pp. 95-103.

Khanam, R., Nghiem, H.S. and Rahman, M.M. (2011), “The impact of childhood malnutrition on schooling: Evidence from Bangladesh", Journal of Biosocial Science, available at:https://doi.org/10.1017/S0021932011000149.

Kilburn, K., Handa, S., Angeles, G., Mvula, P. and Tsoka, M. (2017), "Short-term impacts of an unconditional cash transfer program on child schooling: Experimental evidence from Malawi", Economics of Education Review, Elsevier Ltd, Vol. 59, pp. 63-80.

Langsten, R. (2017), "School fee abolition and changes in education indicators", International Journal of Educational Development, available at:https://doi.org/10.1016/j.ijedudev.2016.12.004.

Lincove, J.A. (2009), "Determinants of schooling for boys and girls in Nigeria under a policy of free primary education", Economics of Education available at:https://doi.org/10.1016/j.econedurev.2008.10.001.

Maertens, M. and Verhofstadt, E. (2013), "Horticultural exports, female wage employment and primary school enrolment: Theory and evidence from Senegal", Food Policy, available at:https://doi.org/10.1016/j.foodpol.2013.07.006.

Millán, T.M., Macours, K., Maluccio, J.A. and Tejerina, L. (2018), "Experimental Long-term Effects of Early Childhood and School-age Exposure to a Conditional Cash Transfer Program Teresa Molina Millán, Karen Macours, John A. Maluccio and Luis Tejerina 1 September 2018”, No. September, pp. 1-85.

Miller, C. and Tsoka, M. (2012), "Cash Transfers and Children's Education and Labour among Malawi's Poor", Development Policy Review, available at:https://doi.org/10.1111/j.1467-7679.2012.00586.x.

Molina Millán, T., Macours, K., Maluccio, J.A. and Tejerina, L. (2020), "Experimental long-term effects of early-childhood and school-age exposure to a conditional cash transfer program", Journal of Development Economics, Vol. 143 No. June 2019, available at:https://doi.org/10.1016/j.jdeveco.2019.102385.

Nanda, P., Datta, N. and Das, P. (2014), "IMPACCT Impact of Conditional Cash Transfers on Girls' Education".

Nicholson, W. and Snyder, C. (2009), Intermediate Microeconomics and Its Application, South-Western, available at:https://doi.org/10.1007/s13398-014-0173-7.2.

Norbert Schady and Maria Caridad Araujo. (2008), "Cash Transfers, Conditions, and School Enrollment in Ecuador”, Economía, available at:https://doi.org/10.1353/eco.0.0004.

Oketch, M., Mutisya, M., Ngware, M., Ezeh, A.C. and Epari, C. (2010), "Free primary education policy and pupil school mobility in urban Kenya", International Journal of Educational Research, available at:https://doi.org/10.1016/j.ijer.2011.01.002.

Orazem, P.F. and King, E.M. (2007), "Chapter 55 Schooling in Developing Countries: The Roles of Supply, Demand and Government Policy", Handbook of Development Economics, available at:https://doi.org/10.1016/S1573-4471(07)04055-7.

Owusu-Addo, E., Renzaho, A.M.N. and Smith, B.J. (2020), "Developing a middle-range theory to explain how cash transfers work to tackle the social determinants of health: A realist case study", World Development, Elsevier Ltd, Vol. 130, p. 104920.

Retnaningsih, H. (2017), "Program Indonesia Pintar: Implementasi Kebijakan Jaminan Sosial Bidang Pendidikan (Studi di Kota Kupang, Provinsi Nusa Tenggara Timur dan Kota Palembang, Provinsi Sumatera Selatan)", Jurnal Aspirasi, Vol. 8 No. 2, pp. 161-177. 
Rosati, F. (2016), "Can cash transfers reduce child labor?", IZA World of Labor, available at:https://doi.org/10.15185/izawol.293.

Rosati, F.C. (2003), "Children's Working Hours and School Enrollment: Evidence from Pakistan and Nicaragua", The World Bank Economic Review, available at:https://doi.org/10.1093/wber/lhg023.

Sabates, R., Bhutoria, A., Sabates-Wheeler, R. and Devereux, S. (2019), "Schooling responses to income changes: Evidence from unconditional cash transfers in Rwanda", International Journal of Educational Research, Elsevier, Vol. 93 No. November 2018, pp. 177-187.

De Silva, I. and Sumarto, S. (2015), "How do Educational Transfers Affect Child Labour Supply and Expenditures? Evidence from Indonesia of Impact and Flypaper Effects", Oxford Development Studies, available at:https://doi.org/10.1080/13600818.2015.1032232.

Skoufias, E. and Parker, S.W. (2001), "Conditional Cash Transfers and Their Impact on Child Work and Schooling: Evidence from the PROGRESA Program in Mexico", Economía, available at:https://doi.org/10.1353/eco.2001.0016.

Snilstveit, B., Stevenson, J., Menon, R., Phillips, D., Gallagher, E., Geleen, M., Jobse, H., et al. (2016), “The impact of education programmes on learning and school participation in low- and middle-income countries", Systematic Review Summary 7.

Son, H.H. and Florentino, J. (2008), "Ex-ante impact evaluation of conditional cash transfer program on school attendance and poverty: The case of the Philippines", ADB Economics Working Paper Series, Vol. 142 No. 142, pp. 1-32.

Suryadarma, D., Suryahadi, A. and Sumarto, S. (2006), Causes of Low Secondary School Enrollment, The SMERU Research Institute.

Tansel, A. (1997), "Schooling attainment, parental education, and gender in Côte d'Ivoire and Ghana", Economic Development and Cultural Change, available at:https://doi.org/10.1086/452309.

Taylor, J.E. and Adelman, I. (2003), “Agricultural Household Models: Genesis, Evolution, and Extensions", Review of Economics of the Household, available at:https://doi.org/10.1023/A:1021847430758.

The World Bank. (2012), "PKH Conditional Cash Transfer. Social Assistance Program and Public Expenditure Review 6", The World Bank.

de Walque, D., Fernald, L., Gertler, P. and Hidrobo, M. (2017), "Cash Transfers and Child and Adolescent Development", Disease Control Priorities, Third Edition (Volume 8): Child and Adolescent Health and Development, available at:https://doi.org/10.1596/978-1-4648-0423-6_ch23.

Widianto, B. (2013), "The political economy of social protection reforms in Indonesia", Social Protection in Developing Countries: Reforming Systems, available at:https://doi.org/10.4324/9780203082294. 